\title{
MOTIVATION IN SPINOZA AND ROSENZWEIG OR TRANSGRESSING THE BOUNDARIES OF A RATIONALLY CONSTRUCTED SELF
}

Jules Simon*

RESUMO - O artigo introduz uma distinção crítica na análise do fenômeno da motivação humana a partir das filosofias de Espinosa e Rosenzweig, através de uma leitura alternativa de suas respectivas concepções de motivação. O ensaio procura mostrar em que sentido o problema ético da motivação implica o conceito de transgressão nesses dois grandes pensadores.

PALAVRAS-CHAVE - Espinosa. Ética. Motivação. Rosenzweig. Transgressão.
ABSTRACT - The article introduces a critical distinction into an analysis of the phenomenon of human motivation out of the philosophies of Spinoza and Rosenzweig through an alternative reading of their respective conceptions of motivation. The essay attempts to show how the ethical problem of motivation entails the concept of transgression in these two great thinkers.

KEY WORDS - Ethics. Motivation. Rosenzweig. Spinoza. Transgression.

In the first place, I propose that both of these philosophers enable us to become different kinds of Grenzgänger - border crossers - by their textual productions and biographical adventures. But more ambitiously, I suggest that the distinctions that differentiate these two philosophers can be brought to bear on developing a general account of human motivation that is in the spirit of the best sorts of ethical theorizing being done today. I would like to begin by pointing out, preliminarily, that motivation presupposes the possibility of a sort of fundamental transgression of the sort that moves someone from one state or condition to another, which means that in order for motivation to have actual significance, one undergoes discernible change. Fundamentally, it seems obvious to me that any ethics entails that we are not only capable of being moved but that when we in fact have been or will in the future be moved we have transgressed some kind of fixed border or limit. In other words, my claim is that motivation is, at its most basic level, ein Gehen über Grenzen - a transgression of borders.

Chair and Associate Professor, Dept. of Philosophy, The University of Texas at El Paso.

\begin{tabular}{|l|l|l|l|l|l|}
\hline VERITAS & Porto Alegre & v. 54 & n. 1 & jan./mar. 2009 & p. 137-160 \\
\hline
\end{tabular}




\section{Transgressing or bridging borders?}

What I am proposing goes against the grain that standard biographies tell us about these two philosophers. For example, in surfing the internet for contemporary 'popular' readings of Spinoza's philosophy, I came upon Daniel Barenboim's website and found an entry that he wrote on Spinoza: "The Purpose of The State is Freedom: Daniel Barenboim on the relevance of Spinoza's Ethics to the conflict in the Middle East - and music" from December 2003. He reiterates a commonly held belief about Spinoza, that:

Spinoza would not tolerate restrictions, imposed by any political or religious system or by any moral attitude. He struggled for the ideal of free thought. Hardly any other philosopher made so many enemies. He was labeled 'a troublemaking Jew', banned from the synagogue and from the academic establishment. Even his pupils would [only] acknowledge him in private. And when Karl Ludwig asked the impoverished lonely philosopher to lecture at the University of Heidelberg, he turned him down. Spinoza could not guarantee that his thinking would not threaten 'widely accepted religious concepts'. The philosopher in him preferred the quiet retiring life to a bourgeois career.

And of course there is Yirmiyahu Yovel's more deeply probing intellectual critique in Spinoza and Other Heretics: the Marrano of Reason, where he makes the case for a spinozistic philosophy of immanence that offered "a religion of reason over and above ordinary rationality, one which expresses itself in science and in practical ethics." ${ }^{2}$ According to Yovel, Spinoza's modern form of salvation rejected all historical religions and cults as superstitious in favor of a kind of this-worldly salvation where eternity somehow permeates temporal life. For all intents and purposes, Spinoza has often been perceived as the heretic and true transgressor of established social constraints and moral prohibitions, for the sake of setting us on the normative path of a better, more rational socio-ethical order.

On the other hand, Rosenzweig has on occasion been referred to as a modern-day Baal Shem Tov, that is, someone who has contributed to the resurgence of a movement toward more orthodox practices and beliefs in traditional Judaism as a way to reject faith in the historicism of his day and an attempt to save history, as such. ${ }^{3}$ The usual starting point for considering such

\footnotetext{
See: "http://www.danielbarenboim.com/journal_spinoza.htm".

Yovel, Yiumiyahu. Spinoza and Other Heretics: the Marrano of Reason. Princeton: Princeton University Press, 1989. 154.

3 See Mendes-Flohr, Paul. Divided Passions: Jewish Intellectuals and the Experience of Modernity. Detroit: Wayne State University Press, 1991. 326: "It may be held that the glorification in The Star of Redemption of Israel's separation from the wiles and hazards of politics and world-history is indicative of Rosenzweig's rejection of history." Mendes-Flohr goes on, however, to complicate this thesis by tracing how Rosenzweig was actually intent on rejecting the historicism of his intellectual forbearers and peers, especially Meinecke's, in an effort to 'save' history through developing his personal and communal ideas associated with 'theological' categories of creation, revelation and redemption.
} 
a movement is by considering how Rosenzweig both rooted himself in the political philosophy of Hegel and then became disenchanted with its political unfolding. Such rootedness can be explained out of his early, academic plan to work out a theory of political philosophy out of Friedrich Meinecke's popular and influential theory of ethical historicism, that is, that ethical ideas are embedded in the course of historical events. That theory was based on the most significant political philosophy of his day, that is, Hegel's. In adopting those ideas, Rosenzweig attained a sense of place grounded in the heritage of the hegemony and sovereignty of a neo-Hegelian Prussian state, an attempt on his part to work out the claims by Meinecke that the ideals and values of an enlightened cosmopolitanism could be synthesized with the particularity of the emerging German nation-state. ${ }^{4}$ This heritage, however, soon led to the conflicts, violence and destruction of World War I, as Rosenzweig came to realize. His disillusioning experience in the trenches during that war combined with the personal challenges surrounding his decision not to convert to Christianity and his intense intellectual and emotional relations with friends and relatives, led him to compose The Star of Redemption. ${ }^{5}$ As is fairly well-known, the journalistic film critic, Siegfried Kracauer considered Rosenzweig's work out of Der Stern to be just another form of apotheosis and in his 1925 Frankfurter Zeitung review of his Bible translation with Buber, wrote that the translation even smelled badly because of its Wagnerian Romanticism, a judgment at least partly shared by Walter Benjamin. ${ }^{6}$ More recently, Peter Gordon orients Rosenzweig in a similar political orbit by closely aligning him with Heidegger in the cultural and philosophical milieu of Weimar, Germany. ${ }^{7}$

But this is not an intellectual history of ideas approach; rather, I am more interested in what these philosophies provide for us in order to better understanding ethical theory, which means that I'm interested in analyzing ethical concepts as a deviation on a Gadamerian hermeneutic Wirkungsgeshichte. To begin with, any ethical theory presupposes some theory of action, which itself presupposes a theory of motivation. We do not find in either Spinoza's or Rosenzweig's philosophies explicit theories of action or of motivation and several thoughtful scholars have dismissed at least Rosenzweig's philosophy on the grounds that it entails a departure from the theater of history. This is a complicated issue given that Rosenzweg's first work, Hegel und der Staat, is both a novel production in intellectual history and, I would argue, is his prolegomena for an ethically oriented philosophy of history set out in Der Stern der Erlösung. In what follows, I present a sketch of how such a judgment of a-

\footnotetext{
Meinecke, Friedrich. Weltbürgertum und Nationalstaat. Studien zur Genesis des deutschen Nationalstaates. Munich: Oldenbourg Verlang, 2008.

Rosenzweig, Franz. Franz Rosenzweig, Der Mensch und sein Werk, Gesammelte Schriften: 2 Der Stern der Erlösung. Dordrecht: Martinus Nijhof Publishers, 1984. (from now on SE)

See: "http://muse.jhu.edu/journals/prooftexts/v020/20.3britt.pdf".

See Gordon, Peter. Rosenzweig and Heidegger: Between Judaism and German Philosophy. Berkely: University of California Press, 2005.
} 
historicism holds with respect to Spinoza but not for Rosenzweig. In the first part of the paper, I interpret select sections of Spinoza's Ethics for its ideas about motivation and the metaphysics underlying his ethical theory. In the second and longer part, I turn to Rosenzweig's Stern der Erlösing to interpret his ideas about motivation, testing them for their susceptibility to be both empirically grounded and groundable. From the Ethics, we learn that Spinoza's most critical concept that has to do with motivation is what he refers to as the phenomenon of the conatus. For a spinozist, we experience both excellence and perfection in so far as we strive to seek our own advantage in a metaphysical system that is entirely and necessarily determined through a cause and effect structure. Out of Der Stern der Erlösung we learn that Rosenzweig's most relevant conceptual structure for ethical theory comes out of his midrash on Shir Ha Sharim that presents motivation as it occurs in the phenomenon of human love as a revelatory relation. In what follows, I offer what I think to be the consequences for a theory of social normativity of their respective positions.

\section{Spinoza}

Spinoza's theme: We love out of enlightened self-interest and we are not, in the first place, altruistically motivated, that is, we are not primarily motivated for the sake of the other.

There is a red thread that runs through Spinoza's Ethics by which the many parts of his ethical argument can be tied together. The thread, however, has two strands that correspond to the implicit duality in his acclaimed defense of monism. The one strand has to do with his foundational metaphysics that is based on a defense of philosophy as that sort of human activity that intrinsically entails affirming the real effectiveness of self-reflective thinking. The corollary to that strand is his argument about the primacy of the conatus as the essential characteristic of self-preservation that is constitutive of all beings, but determining in the first instance the essence of being human. It should not be surprising, then, that we are guided through his work by a constant insistence that preserving the 'self' is inevitably a rational activity.

Let us return to the two-stranded-ness of Spinoza's red thread. Overall, the strands refer to the two attributes, thought and extension, through which-Spinoza argues-humans both know themselves and know substance as nature or god. Almost from start to finish in his Ethics, we are reminded that the blessed life consists in knowing the distinction between being selfcaused and being caused by some external other. In short, we find a consistent insistence that what should constitute our primary motivation is to first and foremost seek our own advantage.

The familiar strains of Spinoza's philosophy are those that play out with the vibrations of substance, attribute, mode, and affections which are, metaphysically, the means by which anything at all is conceived or expressed. And 
the bass note that reverberates through almost every proposition, scholium and demonstration is his premise that knowledge of an effect depends on knowledge of its cause and that, therefore, the most complete and adequate knowledge is knowledge of oneself as causing oneself and as not dependent on another. What this merely means is that the extent to which I am limited by an other, which is the constraint of being defined as imperfectly human in Spinoza's system, is the extent to which I serve as my own source of selfcausation or not. Spinoza's defense of this rather simple premise controls much of what I have to say about his philosophy of motivation.

Indeed, in his opening salvo, Spinoza posits that, "If things have nothing in common with one another, one of them cannot be the cause of the other." (P4)

In other words, in the realm of causation, we must posit a defining sphere of commonality without which there can be no bridge from one entity to another. What this entails is that any one entity cannot be understood through another and any recourse to rationality and thus to an ethical order that values heterogeneity, is blocked off. Spinoza defines what he means by commonality negatively, that is, by telling us that "Things are distinguished from each other by differences in attributes or differences in affections." (P4) The former is not interesting since it is non-contestable, that is, it merely establishes the ground of Spinoza's parallelism, that there is bodily activity and mental activity, two forms that are non-reducible to each other. More importantly, these propositions are steps to further prepare us to accept his claims about the universality and non-divisibility of the one substance that is god or nature. The latter contention, the universality and non-divisibility of god/nature as substance, is directly relevant for how I want to eventually characterize Spinoza's ethical theory, since that means that "God acts from the laws of his nature alone, and is compelled by no one." (P17) In other words, there is no external cause that prompts god (as substance) to act except the perfection of his nature. Preliminarily, then, given that we have to conceive of god/nature/substance as perfect, then obviously there can be no movement or change and thus no intentionality or motivation.

This is because "God is the immanent, not the transitive, cause of all things." (P18) In his commentary on Spinoza, Giles Deleuze correlates the function of "immanent cause" with what he calls the emanative, that is, that sort of cause which is co-extensive with its effect. ${ }^{8}$ He's concerned to answer the question of "how does change happen?" It happens, a la Deleuze, through those sorts of agents or entities that have constituent power. Another way of

\footnotetext{
Philosophical Perspectives on Newtonian Science, ed. By Phillip Bricker and I.R.G. Hughes. Cambridge, Massachusetts: The MIT Press, 1990. On Delueze's anti-hegemony see de Beistegui, Miguel, "The Vertigo of Immanence: Deleuzes' Spinozism" in Research in Phenomenology, Volume 35, Number 1. Leiden, The Netherlands, 2005. pp. 77-100. See also Deleuze, Gilles, Expressionism in Philosophy: Spinoza. New York: Zone Books, 1992.
} 
putting this is that it happens through 'bridging a gap', which is important because every society is defined by the gap or crack that traverses it. ${ }^{9}$ Such gaps become the focal points for 'engineering' creativity, resistance, and change.

But Spinoza's theory also entails a functionalist metaphysics, which was not lost on Althusser who evinced that for any particularity assigned to a totality and for the totality to coexist, the particularity had to perform its function. ${ }^{10}$ This led to Althusser's notions about structural causality, based on his reading of how any particularity is an expression of a totality, namely, that within a total structure, any individual is an expression or local representation of the whole which entails that singularities are determined by the global structure.

An implication in this reading entails accepting theory as a rational construct that is always applied to an object and is thus an interpretation and thus 'merely' a 'reading.' Further, knowledge turns out not to be a matter of 'copying' but is the product of class warfare, as a structuralist interventionist theory. As a Marxist, Althusser contends that the end of theory is action that changes reality and the actual modification of material conditions. For Hegel, however, the end of theory is the re-education of humans and that means further speculation, that is, speculation as a substantive act. Knowledge is not the outcome of the constitutive subject - as it is for Rosenzweig - but the expression of the determination of the structure of the totality.

Spinoza provided the lens for these post-modern structuralist and globalist theories in how he ground out the logical consequences of his theory by introducing the criterion of adequacy as a key component for what motivates the thinking (and thus acting) process. In Part III of Ethics, we find the statement that "Our mind does certain things [acts] and undergoes other things, namely, in so far as it has adequate ideas, it necessarily does certain things, and insofar as it has inadequate ideas, it necessarily undergoes other things." (IIIP1) Can I ever be motivated to hold an inadequate idea? How am I motivated to hold an adequate idea? Already conditioned by the semantics of my everyday language, it should not be surprising that I am more inclined to hold an adequate versus an inadequate idea. But since all action is determined according to the strict necessities of cause and effect structures, it seems I would never even have the choice. For his part, Spinoza chose to use comparative terms of evaluation to persuade us to accept his reasoning and, indeed, Spinoza persuasively points out that "...ideas which are adequate in someone's mind are adequate in God insofar as he constitutes the essence of that mind [only]

9 This insight is from an unpublished work of mine: "Bridging the Gap: from edge to edge" presented at the workshop Doing Phenomenology: Back to the Things Themselves! 2008: "The InBetween/Edges" for the Existential and Phenomenological Theory and Culture society at the Canadian Federation for the Humanities and Social Sciences conference in Vancouver, Canada, May 27, 2008.

10 Levine, Norman. Divergent Paths: Hegel in Marxism and Leninism and Engelism. Lehman, Maryland: Lexington Books, 2006. p. 27. 
(Dem.; by IIP, 11C). And he adds a further psychological caveat: "..if God, insofar as he is affected by an idea which is adequate in someone's mind, is the cause of an affect, that same mind is the effect's adequate cause (by IIP, 11C)."

We need to keep in mind the idea of activity (and thus of perfection) as it relates to that of adequacy, which is especially pertinent for Spinoza's ideas about passions, namely, that '...the mind is more liable to passions the more it has inadequate ideas, and conversely, is more active the more it has adequate ideas." (Cor.) That is, the more it is self-caused. In other words, the more passions that one has, the more inadequate ideas, the less perfection and the less one is self-caused. Again, if I had to choose I would rather have more adequate ideas, be more self-caused, and thus be perfect. But it seems like I would have to resist, somehow, being moved by my passions. But then again, since Spinoza argues against any form of a teleological metaphysics - i.e., non-intentional and non-purposeful metaphysics - in favor of a strictly functionalist rendering of the physics and metaphysics of reality, then perhaps we should not be so surprised.

Such a state of affairs seems to be fine, however, since according to Spinoza, there does not seem to be any reason to consider that "motivation" is anything but an obscure concept anyway: "... no one knows how, or by what means, the mind moves the body, nor how many degrees of motion it can give the body, nor with what speed it can move it. So it follows that when men say that this or that action of the body arises from the mind, which has dominion over the body, they do not know what they are saying." (P2.Schol) What Spinoza means by this is if the body is inactive the mind is incapable of thinking. His proof by example is that when the body is at rest in sleep the mind remains senseless and does not have the power of thinking as it does when it is awake. One question that immediately arises: is this the same power then?

Why "no one knows" can be understood from Spinoza's observations about how he thinks the general lot of uniformed humans erroneously think about the relationships of that by which they are motivated: "So experience itself, no less clearly than reason, teaches that men believe themselves free because they are conscious of their own actions, and ignorant of the cause by which they are determined, that the decisions of the mind are nothing but the appetites themselves, which therefore vary as the disposition of the body varies." (P2.Schol.ii) What is actually the case is that humans, like all beings, are necessarily determined to strive to persevere in their own being. "The striving by which each thing strives to persevere in its being is nothing but the actual essence of the thing." (P7) He goes on to elaborate the simplicity of this function by noting that "... the power of each thing, or the striving by which it (either alone or with others) does anything, or strives to do anything - that it (by P6), the power, or striving, by which it strives to persevere in its being, is nothing but the given, or actual, essence of the thing itself, q.e.d." What any- 
thing essentially is is defined by its power to do this or that to persevere in preserving itself. That's the simple story.

The more complicated version takes up the rest of Spinoza's Ethics and has to do with what Spinoza says about the role that imagination plays in increasing or decreasing the striving to persevere:

"...so long as the human mind regards some external body as present, that is (by IIP17S), imagines it, the human body is affected with a mode that involves the nature of the external body. Hence, so long as the mind imagines those things that increase or aid our body's power of acting the body is affected with ideas that increase or aids its power of acting (see Post. 1), and consequently (by P11) the mind's power of thinking is increased or aided. Therefore (by P6 or P9), the mind, as far as it can, strives to imagine those things, q.e.d." (P12: Dem.)

And to the power of imagination he adds the function of recollection in order to set up a conceptual schema that has to do with association, or what he calls accompanying. This is then how he is able to account for what he calls love and hate: "When the mind imagines those things that diminish or restrain the body's power of acting, it strives as far as it can, to recollect things which exclude their existence." (P13) In the Scholium that follows, he goes on to succinctly state that

"From this we understand clearly what love and hate are. Love is nothing but joy with the accompanying idea of an external cause, and hate is nothing but sadness with the accompanying idea of an external cause. We see, then, that one who loves necessarily strives to have present and preserve the thing he loves; and on the other hand, one who hates strives to remove and destroy the thing he hates."

"He who imagines that what he loves is destroyed will be saddened; but he who imagines it to be preserved, will rejoice." (P19) In the Demonstration, he claims that, "Insofar as it can, the mind strives to imagine those things which increase or aid the body's power of acting (byP12), that is (by P13S), those it loves."11

We are motivated to associate with those who align themselves with our interests or affects, i.e., with those that are moved by the same things that we are; therefore, no actual breaking of boundaries or crossing bridges happens i.e., no transgression, kein gehen über Grenzen-there is no way to accept those who are different than us. Demonstrating the logical coherence that

11 He elaborates further: "But the imagination is aided by what posits the existence of a thing, and on the other hand, is restrained by what excludes the existence of a thing (by IIP17). Therefore, the images of things that posit the existence of a thing loved aid the mind's striving to imagine the thing love, that is (by P11S), affect the mind with joy. On the other hand, those which exclude the existence of a thing loved, restrain the same striving of the mind, that is (by P11S), affect the mind with sadness. Therefore, he who imagines that what he loves is destroyed will be saddened, and so on, q.e.d." Spinoza, Benedictus de. Baruch Spinoza: Ethics. Indianapolis: Hackett Publishing Company, 1991. All of the in-text quotes are from this edition and use the corresponding section designations used by Spinoza. 
earned him immortal fame, Spoinoza goes on to build on that line by stating that we favor those who favor people like us and hate those who injure people like us. You can tell where this is going, that is, it is going along the lines of a metaphysics, and thus an ethics, of homogenization and hegemony. We primarily strive to keep in existence those who make us happy.

Indeed, Spinoza argues that we rejoice all the more when we know that when something (someone) we love esteems us, we regard ourselves with even more joy. The bottom line is that we treat others well in order that they love us in return, that is, the other should recognize that we are the source of her/him being treated well, and we do so in order to know that we are affecting her with joy because that aids our own striving, that is, makes us joyful. And in the process, knowing that we made another joyful makes us joyful about ourselves, as we are joyful about the affect our actions have on another as well as exult at being esteemed by the other. ${ }^{13}$ We always prioritize joy over sadness as the best possible means to preserve our being. To me, this Panglossian lusting after happiness indicates a lack of depth and, given the source, unfortunate superficiality. ${ }^{14}$

The next move is to determine the extent to which the mind (alone) determines happiness because the mind has power over the body and the affects: It is enough, I say, for us to understand the common properties of the

12 Spinoza, Ethics: "If we imagine someone to affect with joy a thing we love, we shall be affected with love toward him. If, on the other hand, we imagine him to affect the same think with sadness, we shall also be affected with hate toward him." And "..so also we favor him who has benefited someone like us, and are indignant at him who has injured one like us." (p. 82) With this logic, we create a community of those most like us, i.e., we strive to keep things or persons in existence who make us happy. See also the supporting propositions:

"Next, joy posits the existence of the joyous thinking (by P11S), and the more so, the greater the joy is conceived to be. [Therefore] if someone imagines him whom he hates to be affected with joy, this imagination (by P13) will restrain his striving, that is (by P11S), he who hates will be affected with sadness, and so on, q.e.d." (p.83)

13 Spinoza, Ethics: "P34: The greater the affect with which we imagine a thing we love to be affected toward us, the more we shall exult at being esteemed." (p. 88) and: "Dem.: We strive (by P33), as far as we can, that a thing we love should love us in return, that is (by P13S), that a thing we love should b affected with joy, accompanied by the idea of ourselves [as cause]. So the greater the joy with which we imagine a thing we love to be affected on our account, the more this striving is aided, that is (by P11 and P11S), the greater the joy with which we are affected. But since we rejoice because we have affected another, like us, with joy, then we regard ourselves with joy (by P30). Therefore, the greater the affect with which we imagine a thing we love to be affected toward us, the greater the joy with which we shall regard ourselves, or (by P30S) the more we shall exult at being esteemed, q.e.d."

${ }^{14}$ Compare also: Spinoza, Ethics: "P34: The greater the affect with which we imagine a thing we love to be affected toward us, the more we shall exult at being esteemed.xxc" and "Dem.: We strive (by P33), as far as we can, that a thing we love should love us in return, that is (by P13S), that a thing we love should b affected with joy, accompanied by the idea of ourselves [as cause]. So the greater the joy with which we imagine a thing we love to be affected on our account, the more this striving is aided, that is (by P11 and P11S), the greater the joy with which we are affected. But since we rejoice because we have affected another, like us, with joy, then we regard ourselves with joy (by P30). Therefore, the greater the affect with which we imagine a thing we love to be affected toward us, the greater the joy with which we shall regard ourselves, or (by P30S) the more we shall exult at being esteemed, q.e.d." 
affects and of the mind, so that we can determine what sort of power, and how great a power, the mind has to moderate and restrain the affects." (101 P56S) The mind turns out to be the determining function for Spinoza in how we modify the attachments we may have to those entities external to our mind/body. This position may have been tempered by his comments regarding desire, but his use of that term turns out to be a synonym for the affects as appetites. In fact, Spinoza claims that "desire is the very nature, or essence, of each [individual]" as the striving to persevere in one's being itself. ${ }^{15}$

It seems that for a Spinozist, one is motivated to continue to function best by striving to serve one's own interests, first and foremost, which means serving the impersonal dictates of the eternal mind of god, or nature.

\section{Rosenzweig}

Rosenzweig's theme: we are motivated out of a desire for the unpredictable other, which is primarily affirmative (as opposed to primarily negative, as with Spinoza); that is, in order to affirm my own self and identity as meaningful, I am firstly motivated to affirm the other, to receive by giving, to speak by listening and thus to engage in actually effective dialogue that moves others and myself - that is 'movingly' meaningful - and thus build community one Steigerung step at a time.

As with Spinoza's philosophy, there is a red thread that runs through Rosenzweig's Der Stern der Erlösung by which the many threads of the tapestry of his work are held together, and that is his wedding of the dynamics of a theory of speech-thinking as a form of speech-acts that both compels rational engagement and yet resists ultimate systematic coherence. That uneasy and uncertain wedding is none the less essential because in order for his work to effect its magic on the reader, we need to move in and out of this and that section in preparation for the most important movement, that is, our motivation to engage in an ethical relation with an actual other and many other actual others. The crux is to become motivated to engage in the process of Steigerung (progressive increase), a process that entails having to take into constant accounting in our engagements with others in and with the world, what he calls the conjoining of the sinnlich and the übersinnlich, the sensual and the trans-sensual. Where Spinoza puts the lens of his geometrical method in our hands to better see and thus understand the ethical implications in the

\footnotetext{
${ }_{15}$ Spinoza, Ethics: "P57D. All the affects are related to desire, joy, or sadness... But desire is the very nature, or essence, of each [individual] (see the definition of desire in P9S). Therefore, the desire of each individual differs from the desire of another as much as the nature, or essence, of the one differs from the essence of the other.

Next, joy and sadness are passions by which each one's power, or striving to persevere in his being, is increased or diminished, aided or restrained (by P11 and P11S). But by the striving to persevere in one's being, insofar as it is related to the mind and body together, we understand appetite and desire (see P9S). So joy and sadness are the desire, or appetite, itself insofar as it is increased or diminished, aided or restrained, by external causes."
} 
parallelism of body and mind, Rosenzweig provides us with a prism. The prismatic phenomenon means that, with the help of structured guidance of the prismatic Star, we learn how to actually bridge gaps between the physicality of experiences, such as the reading experience itself or listening to a spoken lecture, and the content of my reading or and the meaning of the content or of the phenomenon of speaking as such, by way of learning how to effectively engage in empirically prismatic plays of word and answer, and thus of responsibility.

For a Rosenzweigian, a Spinozist metaphysics of self-service is ultimately unacceptable. This is so because the basic premise subtending Rosenzweig's philosophy is to resist at every turn being reduced to this or that excellent functioning model-machine. In fact, one of the peculiarities of Rosenzweig's thought is the way in which he maintained that chaos is not some kind of preexisting state of nature - as if we could even know such a state in the first place - but remains ever a part of the workings of the world in which we live. What this means is that at the heart of Rosenzweig's work dwells an ineluctable insistence on the eventual unpredictability of our encounters with others. This presupposes relationships that combine trust with uncertainty, belief with calculation, and desire with fulfilled (or, often, unfulfilled) self-satisfactions. Given those sorts of Grenzen (borders), his theory also entails that we must ever-renew our dialogues with each other because an actual dialogue should never be based on the premise of attaining this or that condition of excellence. All modeling, in fact, becomes various narrative frameworks for working through the actual transitions of our lives. In this sense, Rosenzweig's writing, that is, Der Stern der Erlösung, prepares us to move beyond prescribed limits, to transgress fixed borders, and to become very un-Spinoza-like Übergänger those who transgress fixed borders.

In Rosenzweig's philosophy, we find a much different emphasis on motivation than in Spinoza's. Specifically, Rosenzweig's helps us to resist reducing our experience of reality to either logical or psychological indices but instead encourages us to perceive the richness of our experience through providing set pieces of analyses as already embedded in textual, historical, aesthetic, and ethical relations motivated by these or those confluences of historical agents acting with and on each other (and others). Unlike Spinoza's lenses that were ground into axiomatic functional objects with which to see the connections of the world more clearly, Rosenzweig's philosophy provides us with textual and conceptual prisms both found and artificially made with which our own experiences are transformed and become transformative. ${ }^{16}$ With both found and constructed prisms in hand, we are better able to interpretively approach the limitations and boundaries that occur in our own lives, such as

An n-prism, made of regular polygons ends and rectangle sides approaches a cylindrical solid as $\mathrm{n}$ approaches infinity. 
various forms of self-aggrandizing arrogance or the egoism of the survive-atany-cost ethic.

What I consider to be the refraction of a prismatic experience that characterizes Rosenzweig's writing, reveals the flaws in our conceptions about the self-sufficiency of our own constructive abilities. We depend on the historical prisms that we find in our world, such as various midrashim or theories or textual treatises or art works to make sense of the limits of our lives. Significantly, even our own ability to express what constitutes our own characteristic originality depends on how we respond to the prismatic words spoken by another. What causes me to pause long enough or even at all to suffer through the reception of the intrusion of another on our relentless drive to survive or to achieve the dominance of my independent sovereignty? How am I ever able to articulate a humble admission of my previously self-satisfied yet tragically hued arrogance? We learn from Rosenzweig that there are as many infinite ways to utter "here I am.. I have sinned" as there are to change the colored reflections of the light that plays through the prisms that Rosenzweig constructs. This is the gift that he gives us and as it is held in my hand I intentionally illuminate this or that object with a varying play of light and color. A Spinozist could never admit that she sinned, and thus could never teach us anything about becoming an Übergänger. Guiding us beyond his narrative of sinning, however, Rosenzweig motivates us to read differently by leading us through the motions of reading and thus of interpreting our situations with a preemptively Derridean differance. The heart of Rosenzweig's textual production is a textual midrash that prismatically colors each of our reading experiences both normatively and uniquely, but not universally, and is thus inherently motivational.

By now, the careful reader should be able to detect the contours of my thesis, namely, that in order to determine how the normativizing effects of Spinoza's and Rosenzweig's philosophies contribute to a theory of motivation, I need to assess the conceptual tools their works provide for establishing or transgressing metaphysical and ontological claims, which results in being better able to assess the divergent tendencies in their epistemological and ethical conclusions. Given that Rosenzweig's methodological approach to philosophy is primarily midrashic, ethical, and narrative rather than rationalist, metaphysical, and expository as is Spinoza's, upon entering the narrative framework of Der Stern der Erlösung we find ourselves immersed in a series of mini-narratives, one after another but also one embedded in many others. This is a typical phenomenological choice for how to engage and motivate readers, that is, rather than providing us with axioms, definitions and propositions to move us along in an ever-more constricted order of a reading practice that is based on causally determined inferential lines of thought, Rosenzweig demonstrates his commitment to a dialogical and pluralist social realm that is multivalent, dialogical, and reliant on an ever-shifting prismatic play of light that occurs with every new reader who takes up his challenging task. In other 
words, rather than leading us into an ever-tighter system of constraints (as with Spinoza), we are led from one threshold or limit in our textual adventure to the next, in order to ponder how to cross and when or if we are even able to cross from one realm into another of the text. As we move along in our reading, we find ourselves traveling through transitional bridges and before we are entirely aware of the change in perspective, we are already immersed in a different thought-world that reorients us to our engagement in and with the world itself and other beings of the world. This intentional design on Rosenzweig's part is designed to immerse us in a peculiar kind of philosophy of history, or better yet, philosophies of history that are meant to motivate us to reconsider the historicity of our own epistemic commitments and ethical relations.

What I mean by that is based on how I understand the purpose embedded in the results of Rosenzweig's historical accounts and textual exegeses. The gist of this sort of work on his part is that by preparing ourselves to become more familiar with the actual historical development of, for example, the scientific traditions of physics, logic, and ethics we can achieve relative orientations to working with the ongoing developments in those fields, a process that he denotes as metaphysics, metalogic, and metaethics. ${ }^{17}$ By the end of the Übergang ("Transition" section), we are told that what we just experienced in our reading was actually the "doctrine (or teaching) of the elements":

Elementarwissenschaften, d.h. gewissermasssen Wissenschaften von den Vorgeshichten, von den dunkeln Gründen des Entstehns; die antike Theologie, Psychologie, Kosmologie gilt uns also sozusagen für Theogonie, Psychogonie, Kosmogonie. (98)

But even these histories provide us with different aspects of origins: the theogonie provides us with the birth story of god which provides us with a temporal index [Anzeiger oder Verzeichnis] of the past; the psychogonie provides us with the birth story of the soul which is an index for the present life; and the cosmogonie provides us with the birth story of the world which is an index for the future. We are being prepared to orient ourselves for the move from the introverted self as it historically matures by actually experiencing a conceptual movement motivating us through experiencing the different phases of actuality as prismatic, and thereby preparing us for an encounter with another self that is and can never be like unto myself. In preparation for this move, Rosenzweig must work out a theory whereby he reinvests the objective authority of history itself as fundamentally interpretive and subjective in its application, which he eventually does through his introduction of midrash in the Herzstück of the text, that is, with the chapter on revelation itself.

With this explication of histories that moves us from traditional epistemic categorizations to a new sort of Wissenschaftslehre, Rosenzweig is able to

See Book 1 of Part II of SE. 
lead us into and through the transitional chapter, "Vom Wunder," by engaging us in a series of historical reflections around the theme of the history of "miracle." That history is marked by the Auseinandersetzungen of thousands of years of struggle between philosophers and theologians battling with each other for what 'miracle' — as both conceptual term and phenomenon-should mean, from its one-time exalted status as the sign of lawfulness (Gesetzlichkeit), as it was used in the prophetic tradition, to its contemporary status as an embarrassment (Verlegenheit) for rationally trained, scientifically enlightened modern thinkers. Rosenzweig frames this particular history as a narrative of speech-acts that ultimately have to do with both revelation and the phenomenon of temporality.

He is quick to point out that the move to affirming the present effect of revelation post-1800 by theologians such as Schleiermacher comes on the back of the new principle of progress, emphasizing only the two temporal dimensions of present and future. One is motivated merely by a belief in the "inner breakthrough of grace" based on a "trust in [the] future effect [that it would have] in life" rather than by a trust in creation as that which is already there outside of, so to speak, and that serves as an objective vehicle for exterior motivation. ${ }^{18}$

From Rosenzweig we learn that with respect to motivation there are two poles. On the one hand there is the one-dimensionality of systematicity as such, which takes the form of absolute objectivity and thus kills all motivation; this could be either Hegelian or Spinozist. On the other hand, there is the multi-dimensionality of form, the "simple plurality of worldviews" that leads to the absurd limits of "philosophizing in aphorisms" with Nietzsche and the nihilists - and takes the form of absolute subjectivity. Rather than accepting this polarization, however, we can strike out a middle way by crossing the borders or limits, and become Rosenzweigian Grenzgängern-creating a world where theologians will philosophize and philosophers will theologize, that is, a world where theology is understood as that phenomenon that provides the sort of discourse for humans to become transformed into receivers of revelation and experiences of being freed from one's socially and environmentally induced prejudicial limitations:

Die Philosophie also wird heute von der Theologie herbeigerufen, um, theologisch gesprochen, eine Brücke zu schlagen von der Schöpfung zur Offenbarung, eine Brücke, auf der dann auch die der heutigen Theologie zentral wichtige Verbindung von Offenbarung und Erlösung geschehen mag. (119)

In such a world, philosophers anticipate theology by constructing its foundation in their function as indicators (Aufzeigen; index) of the precondi-

18 SE, 111. What I mean here has to do with how I consider Der Stern to be 'an empirical example' of an extrinsically created thing. In this way, the star functions as an actual, empirical object that is both at-hand and in-my-hand, so to speak. 
tions on which theology rests. For their part, theologians no longer seize (fassen) their contents (Inhalt) as experienced or earned content (Gehalt) but as event (Ereignis), not as life but as lived experience (Erlebnis). This is one level of transgressing borders, of gehen über Grenzen.

These foundational notions of rehistoricizing are directly relevant for a Rosenzweigian theory of motivation since, unlike the predictability of Spinozist theory, a Rosenzweigian theory of motivation necessarily relies upon exterior factors to initiate movements that become acts. We are moved to act out, breaking through the monadic shells of isolation or interrupting the centripetal reveries coiling around the tragic self. This is, simply, another way of talking about what Rosenzweig means by revelation since what occurs in the phenomenon of revelation is an incursion of the unexpected word or prismatic inspiration of an other as that one who unexpectedly moves me to respond in the first place. This means that in order to understand motivation by Rosenzweig we need to understand his theory of speech-thinking, or better yet, how his theory of speech-thinking is a theory of speech acts that move us from one edge to another. In other words, his theory of language corresponds to a theory of motivation that entails transgressing limits as we move from one language domain to another.

\section{Speech-Thinking as Motivating Speech-Act}

There are many passages that Rosenzweig helps us to cross or transgress, the most obvious of which are those that occur within specific genres. For example, at the end of each of the three books of Part I Rosenzweig presents three formal principles of aesthetics that guide us into his philosophy of art, namely: outer form, inner form, and content. Each of those principles corresponds to not only different kinds of art but to different kinds of life experiences. Those three are: epic/narrative, lyrical/poetic, and dramatic/performative. Additionally, each Book of Part II ends with Rosenzweig's exposition of a section of biblical text as a demonstration of the art that the text and our reading of it comprises. Besides integrating readings of biblical texts as exemplars, Rosenzweig focuses our attention on reflexively rethinking about art itself in terms of the application he develops to that point in his own work. In Part I the perspective developed is epistemological, as Rosenzweig opposes his philosophical 'absolute empiricism' to the Idealist thinking and aesthetics which has reigned from Plato to Hegel. ${ }^{19}$ In Part II, Rosenzweig develops an alternative aesthetics based on his philosophy of language, developing a perspective that moves us from a philosophy of the written word to a

${ }_{19}$ See Rosenzweig, Franz. "Das Neue Denken" in Franz Rosenzweig, Der Mensch und sein Werk, Gesammelte Schriften: 3 Zweistromland, Kleinere Schriften zu Glauben und Denken. Dordrecht: Martinus Nijhoff Publishers, 1984, p. 161, where Rosenzweig claims his method is an absolute empiricism, an "absoluter Empirisimus." 
midrash on the dialogically spoken words of song, a necessary move done in order to more adequately present what is involved in ethically responding to a radically other being. The next movement is to the dimension of performative language, aesthetically enacted and embodied in actual communities, in order to form identifiable and enduring communities that are not only distinct in themselves but are composed of diverse individuals. The art form is communal because it is based on ritual and liturgy as well as all of the other art forms: written and spoken speech, song, poetry, dance, and architecture. Ultimately, we are drawn into a movement, away from unhealthy and unethical Idealistthinking and towards the speech-acts of a revelation-thinking that entail the related dimensions of creation, revelation, and a redemptive messianic politics.

The process for getting to know these other histories happens through sharing the words that make up the histories of one narrative with the other, intertwining chords of one's own story with those of the other in constellations of complex choral fugues. ${ }^{20}$ But in such sharing, words are also withheld in order to be receptive to the other, intentionally suffering, undergoing the passion of not-speaking in order to attend to the other as other. This withholding is for the sake of the other, as a way to prioritize their desires and needs. In Rosenzweig's particular case, a completed text is intentionally left as an open project because even though it is a completed work it is not definitive since that would undermine its essential ethical and thus anarchic character. The openness allows for a sense of the chaos of possibility, of actual anarchy embedded in a ritualized structure denoted as infinitizing the finite, a process - if freely adopted - that continually allows for the possibilities of criticizing the violence of political totalitarianism.

But the sub-logic that is developed depends on the 'drive' that results from being awoken to vitally hearing and speaking with the one, the lover. This drive transforms the beloved into the historical effectiveness of a publicly hearing and speaking lover herself that simultaneously motivates the heart of the beloved-turned-lover to "drive to the outside." ${ }^{21}$ Rosenzweig envisions this motivating process as entailing the process of becoming an actual 'figure' - a Gestalt - in actuality. That is, in order to 'count' and to be able to act effectively as a responsible agent in the history of the world, the enclosed, secluded, and apparently mystical relationship of lover and beloved has to become a Gestalt in reality.

The key to becoming a Gestalt in reality is that the self has to become effective (wirksam) and in order to become effective she has to become a whole human (ganzen Menschen). The way to become a whole human is by becoming immediately visible and audible-one is then no longer a 'dumb' and

\footnotetext{
A German used to capture this sort of interpersonal knowledge is: "jemand oder etwas kennenzulernen."

21 SE, 230: Trieb nach außen.
} 
tragic and speechless statue but, rather, one 'speaks' and one "sees oneself."22 To make his point, Rosenzweig introduces the phenomenon of ancient Greek dramatic tragedy, recasting his aesthetic under the terms of redemption in the form of the performing arts, because that specific art form includes a plurality of art forms such as an audience and an entrance onto the stage of actual life. Indeed, one consequence of becoming "a Gestalt in reality" is that, in no longer being a tragic hero on the stage, one is thrown into the world having overcome death through love by having experienced the fleeting ephemerality and 'unfaithfulness' of love and thus desiring more, infinitely more. This desire is itself a transgression and serves as the key to motivate one to move beyond the borders of one's self-enclosedness to the realm of the eternality of a loving relation.

But in fact, for love to become eternal, one has to first fully embrace one's own mortality, which means rephrasing the question of the meaning of existence. Such 'rephrasing' is inevitable since 'fully embracing one's mortality' crystalizes in the tragic but autonomous defiance of the human self explicated by Rosenzweig in Part I of Der Stern. However, seen through the prism of his midrash on the Song of Songs, the meaning of existence becomes the passionate sacrifice of one's defiant independence to the effective acts of listening and responding to the desires of the loved one, actually fracturing one's 'cyrstaline' wholeness for the sake of that particular other. While one wholeness is lost - that of the tragically isolated but integrated self - Rosenzweig re-figures the phenomenon of wholeness through considering the 'drama' of life. Unlike the tragic hero of Greek drama, who is visible but ineffective, or the selfenclosed figure of the mystic saint who can only wait for god to come again to him in a mysteriously divine rapture, Rosenzweig looks to establish connections between the loved human-become-lover and the world. But in order to establish connections of actual, historical effectiveness the human has to become whole (der Mensch zum ganzen Menschen erschließt) by doing one's own effective (wirksam) act in the world. In the modern era, the human was thrown into the world as a 'whole human' similar to the aesthetic phenomenon of the new tragic hero in modern tragic drama, and is thus "very human and all his limbs quiver with the sound of mortality." ${ }^{23}$ But what is very new in the modern tragic drama is that the human on the stage compels the spectator in the audience into a dialogue, into a "feeling of being his occasionalpartner-in-speech" (das Gefühl seines Mitunterredner). Unlike in Greek tragedy, the spectator does not identify with the actor in an Aristotelian catharsis of fear and compassion but, rather, is drawn into contradiction and a sense of being torn-out-of-with-the-other. The difference is that through Aristotelian aesthetics one remains ever only on the verge of life with merely informed

\footnotetext{
22 Ibid, 233.

23 Ibid.
} 
premonition, whereas in modern tragic drama the spectator's volition is aroused and becomes engaged.

Perhaps even more importantly for Rosenzweig is that this 'new' development, that the spectator's 'will' is aroused and not their mere cognition, entails an ethical imperative to act out of the two-alone-ness and momentariness of the love relationship. Without the sense of being-torn-out-of (one's seclusion) and arousing of one's will, or drive, there could be no turning to the next one 'beyond' the chosen one. Precisely here, Rosenzweig's 'messianic aesthetics' comes into view, that is, the 'next one' is chosen as one chooses a messiah - which is precisely what I would call a messianic politics. In another context, Walter Benjamin would refer to this form of treating the other by caring for their material needs and spiritual desires, and by doing so looking forward to the generation to come, as a "weak messianism." 24 Learning to discern the cues of my social relations along Rosenzweigian lines, I learn to treat the next one as I have been messianically chosen-each next other is the messiah to my creative love, being singled out and chosen from the crowd in a play of choosing and being chosen in an asymmetrical dynamic of caring for the other's needs and desires.

Only at this point does the ethical divergence of Spinoza and Rosenzweig come into anticipatory focus by considering how Rosenzweig treats the tragic hero versus the saint, that is, the holy one. In introducing the concept of the solitary self as either tragic hero or holy one, Rosenzweig explores differences of speech forms used by actors in different settings, distinguishing between classical tragedy and modern tragedy. The form of speech that characterizes classical tragedy is monologue, which he characterizes as only a momentary span of consciousness in an I-standpoint. He sets this the momentariness of this I-standpoint over the ephemeral nature of the love relationship.

In their love for and with each other, lover and beloved court the danger of becoming even-more-secluded from visibility in the world. In order to address this danger, Rosenzweig turns to the drama of tragedy: in pagan, classical tragedy the 'hero' is silent, that is, muted in the isolated-but-integrated defiance of his metaethical self. But in spite of his defiant isolation, the hero is still visible to the world. The chorus, which makes the tragic incommunicability of the heroic self apparent to the spectators by explicitly telling them so, stands for the world at large and swells towards the hero. Rosenzweig notes that only because the hero maintains visibility and elicits reaction from the

${ }^{24}$ See Walter Benjamin, "Über den Begriff der Geschichte" in Walter Benjamin: Illuminationen Ausgewählte Schriften (Frankfurt a.M.: Suhrkamp, 1977), 252: „Dann ist uns wie jedem Geschlecht, das vor uns war, eine schwache messianische Kraft mitgegeben, an welche die Vergangenheit Anspruch hat." See also my essays on drawing the messianic aesthetic out of the works of Benjamin: "Benjamin in Paris: Weak Messianism and Memories of the Oppressed" in Topographies du Souvenir: "Le Livre des passages" de Walter Benjamin, edited by Bernd Witte. Paris: Presses Sorbonne, 2007; and "Rosenzweig's Messianic Aesthetics" in Franz Rosenzweigs Neues Denken, edited by Wolfdietrich Schmied-Kowarzik. Freiburg, Albers Verlag, 2006. 407-417. 
crowd is there anything like 'world' at all in classical paganism. But the 'hero,' while creating a focal point for the gathering of the chorus and anonymous crowd, none the less remains separate, wearing his magic cloak of invisibility by turning his likewise magical Gyges ring. ${ }^{25}$ This condition of the dramatic tragic hero is analogous for Rosenzweig to the mystic, who does have a revelatory relationship with god by virtue of having been chosen and singled out from all others. However, the mystic remains closed off from the world in attempting to remain open to god, arrogantly retaining possession of his ownmost relationship with god, believing that he could possessively retain forever the status of being the only chosen one. In doing so, he remains reactionary and treats the world as if it did not exist, or worse, as if a Cartesian evil god had created it as an evil to be avoided. Rosenzweig characterizes this standpoint, of waiting and being wrapped up in oneself, as "an immoral relationship to the world." ${ }^{26}$ He finds it even more deplorable because the mystic, having been loved, had and lost the chance to contest with the hero for the sake of the world. The problem is that it is insufficient to merely remain in the state of being acted upon, of being the victim of circumstance or of a tragic flaw. Rather, being loved should create the desire to love another, in another singular act of love that is visibly figured as a Gestalt in the world. But that requires acting. (225)

The one who reaches beyond this limitation and enjoys living in the absolute is the saint - the holy one, the healed one, the whole one - der Heilige. For Rosenzweig, only the servant of god, the holy one, is able to do so because she is that one who serves others - according to her own Daimon (one's particular spirit) - that is, as an expression of her own 'Art' that she has learned by traveling down into the depths of the underworld of her own creative spirit. Ironically, however, even the saint needs the help of Mephistopheles and the keys of 'nothing' in order to learn that her human life of character is given direction by having been loved in the first place. The direction that she is given and by which she is defined is the command to love one's neighbor as the love for the next other who happens along (Liebe zum Nächsten). The saint lives absolutely in the absolute, in a tragedy that is only ambiguously possible for the modern tragic poet or character, but is a way of life that is the antithesis of the condition of the Antique tragic hero, that is, the antithesis of tragic seclusion. The saint is the complete one, namely, that one living absolutely in the absolute and therefore "disclosed to the highest ... [while] ... the disclosed human ... [stands] ... in contrast to the hero, ... [who is] ... enclosed in the ever-same darkness of the self." ${ }^{27}$ The "holy one' has experi-

\footnotetext{
25 Note Levinas' treatment of the Gyges myth to present the phenomenon of 'holding something in reserve' as in giving with the anticipation of getting a return for an investment which, I would contend, he learned from Rosenzweig. Levinas, Emmanuel. Otherwise Than Being or Beyond Essence. Pittsburgh: Duquesne University Press, 1998. p. 145.

26 SE 232.

27 Ibid, 236.
} 
enced being loved and the awakening of desire, which is overpowering enough to transform tragic defiance into humility, the breaking of the encrusted, reified self as a movement opening towards and for the other who has turned to the self despite its own arrogant disrespect of that other.

But besides the overflowing power of love-as-desire, Rosenzweig claims that another power has to break forth from the soul in order to not only 'drive' the holy healed one towards the next one, but to give constancy and structure to the ardor (Inbrunst) of the holy one so that the holy one does not resort to a mystic aloneness. ${ }^{28}$ For Rosenzweig, this entails factoring in the temporal process of structural formation aimed at a redemptive future. The source for this additional structuring power comes from within the nature of the self: while desire stems from the "hotly cooking defiance" of the self, which turns into humility, the other dimension of the self that is its "calmly standing water." ${ }^{29}$ This latter source of calm reserve is its way of being as character, its own uniquely peculiar way of being human. Such peculiarity is also what Rosenzweig means when he speaks of how the Daimon of each human being after having been loved becomes compelled to seek a way to express their inimitable uniqueness into the open, in the 'face' of the public. The way that human 'nature' works for the tragic hero in Antiquity is that the assertions of defiance which result in the ever-more-enclosed figure of the tragically silent self are 'affirmed' by the constancy of character, a character which is a result of a once-and-for-all-time mixing of the elements. This constancy of the tragic hero is just what makes him a hero, thus eliciting sympathy from the spectators since the hero is 'stuck' with his tragically flawed character and its uneven mixing. He is stuck with his tragic flaw.

But upon having been loved and attended to precisely in one's uniqueness as the chosen one, the character of the tragically enclosed figure is stimulated to turn inward in order to transform the once-and-for-all-time affirmation into "a source of an ever-renewed self-negation of its origin, the enclosed self, to become that which is wrestled out of itself." ${ }^{\prime 3}$ This is the new work of the ensouled self, namely, assimilating the process of the loving, creative god, by spontaneously renewing itself in every moment through the taking on of passion while remaining true to the destiny of its own force (die schicksalhafte Gewalt). But the problem is that, while both processes are similar in their momentariness, destiny does not impel the human in the same way as it does the god; rather, character does. There is no "must" that necessarily drives the human; a particular Daimon does. Early in his text, Rosenzweig differentiates personality from character, defining personality as that which emerges on the occasion of one's birth while character is a relative latecomer, suddenly overcoming the human, one day, one moment - like being chosen out of a crowd

\footnotetext{
Ibid.

Ibid.

Ibid, 237.
} 
for no apparent reason whatsoever. But the distinction that Rosenzweig makes is even more important for my thesis, that is, that while personality institutes an enclosure (Anlage), the event of emerging character creates a division from the multiplicity of enclosures, from other selves. Once a human is 'possessed' by her Daimon, she is given a direction which she then has for her entire life and that determines the path along which her 'will' runs, determining each and every relationship for the rest of her life. In fact, receiving such directiveness signifies an ethical orientation as well: "Since he has received direction (Richtung), he is already, in truth, judged (gerichtet). Because that which in the human underlies judgment, the essential will, is already fixed once and for all in its direction." ${ }^{31}$ What is striking in this passage is how clearly Rosenzweig establishes the connection between the possibility of directed orientation, as an ontological phenomenon, and an ethical condition, namely, that of being judged. Rosenzweig makes the connection by way of semantically playing with the terms for direction, "Richtung", and judgment, "Gericht", which share the same etymological root. To concretize the connection, he uses the past tense form of the verb for directed, "gerichtet," to refer to how the will is fixed and to insure that we do not miss the double entendre.

But the essential point is that the direction and judgment are themselves both interrupted - Rosenzweig notes that they are 'broken up' and yet strengthened with the call of the other in revelation, precipitating an inner conversion. The willful direction remains willful direction but with the inner conversion it changes from being 'fixed once and for all' to become "capable of renewal and of actual renewal of itself." ${ }^{32}$ But such re-working is neither short-lived nor arbitrary; rather, in every one of the individual acts of willfully directed character, "the whole force of the firmly directed character which has merged in it" becomes able to be applied. ${ }^{33}$

What breaks out of the human in this ever-new force and with one's whole will is the love that was given to the human coupled with the revelatory commandment to love. More specifically, the force takes form as a command to 'love one's neighbor' (die Liebe zum Nächsten). It is 'commanded' and not merely as a consequence of freedom, because it presupposes having already been called, having already been chosen, attended to, and loved. This is an important ethical point, since Rosenzweig points out that only in loving one's neighbor, and thus fulfilling the 'command to love' one's neighbor, is the human first able to express herself. What makes Rosenzweig's claim even more compelling for an aesthetically charged ethical theory is in how he argues that such an expressive act is other than any other moral act, specifically those typically dictated by the normative formalism of Kantian moral law. But it is also other than the ontological ethics described in Hegel's philosophy.

\footnotetext{
Ibid, 238

Ibid.

Ibid.
} 
What distinguishes the command to love one's neighbor from the moral law is the matter of content embodied as a matter of an 'act of love' in the sense of a very concrete acting (Handeln) in the world. As Kant makes clear, the demand of 'autonomy' entails that any act that has its origin in the will must be free and pure of any determination, of any content. ${ }^{34}$ If there were a content, a something or a someone which determined the will, then the will would lose its absolute freedom and thus its autonomy. Kant begins his famous argument for the moral law by asserting that it is the will that is good in itself that enables us to act ethically, and that the human has the ability to simply will. Consequently, every human being - as rational - stands in need of guidance by the formal and necessary guidelines of the universal and universally binding 'moral' law. Rosenzweig counters that demand by asserting that any will that acts without content necessarily results in uncertainty. ${ }^{35}$ As Rosenzweig points out, the consequence of such a logic is that, if everything in morality is uncertain then nothing is in certainty moral. By contrast, instead of a merely formal law of morality, the command to love one's neighbor is clear and concrete and springs from the directed will of the freedom of character. The content is 'to love' the other who comes into one's immediately sensual proximity and is based on having already been loved and is thus invested with the 'memories' of particular, historical concretions.

However, Rosenzweig recognizes the dangers of historical determinism as well, and introduces a further constraint. The new love-act has to be able to break forth afresh, in chaotic fashion, ever-fresh from the beginning. If it was 'fixed' to a willful purposesiveness in some kind of organized schema of acts directed out of a determined past or to some goal in the future, then it would not have the essence of a momentariness of love. Instead, it would be a oncefor-all-time 'patterned' act that was indeed purposive but would not emerge "fresh from the moment." In fact, the dominant characteristic of such reified fixedness, which Rosenzweig identifies with the "way of Allah," is its insistence on a "once-and-for-all-time decided and enclosed obedience." ${ }^{36}$ Rather, in order for an act of love to be effective (wirksam), it must, above all, be "surprising" in such a way that the breaking forth of the love-act provides an always new shattering of the enduring form of character.

At issue is how the relationship between the lover and the beloved develops. Even though the loving-one loves solely the beloved only in this singular moment with the greatest measure, the lover experiences with each new day merely that part (just that Stück - that passage) of life which he loves, and

\footnotetext{
${ }^{34}$ See Kant, Immanuel. Foundations of the Metaphysics of Morals. Trans. \& intro. by Lewis White Beck. Uppers Saddle River, N.J.: Prentice Hall, 1995. p. 43: "For in morals, the proper and inestimable worth of an absolutely good will consists precisely in the freedom of the principle of action from all influences from contingent grounds which only experience can furnish."

35 SE, 239: "Und weil so das Gesetz zu keinem Inhalt kommt, so kommt ifogedessen auch die enizelne Taat zu keiner Sicherheit."

36 Ibid, 240.
} 
which is not ever loved so much as one loves that other today: "every today love loves the beloved a little better." ${ }^{137}$ Rosenzweig names this process Steigerung, and means by that a kind of progressive climbing as a process that takes the form of a transcendence that reveals what is both certain and enduring in the transitoriness of a love relationship. In contrast to the moment of sinking into the realm of the Mothers (referred to above and at the end of his Introduction), with the revelatory relation of love one is able to transcendently rise from one loving moment to the next with the confidence of having positively engaged with an other and thus having effected actual - and enduring change in the world. ${ }^{38}$ Indeed, this progressive movement begins with the former process of sinking into the realm of the Mothers as highly abstract and conceptual in nature, which changes into the regular intensified gradation of the process of Steigerung that takes the form of something concrete and particular coming into enduring existence. Steigerung, as an elevating transcendence - a raising of the particular out of the anonymity of the individual-genus relationship, connotes that which stands out from the rest because of the strength of the connection that is forged in the moment. ${ }^{39}$ What Rosenzweig has in mind is the forging of a form of relationship defined by such German nouns as Bestand, Beständigkeit, and Treue as well as the verb bestehen, which entails "withstanding a test. ${ }^{40}$ To summarize, this concretizing structural process constitutes the enduring formation of actual human communities that consist of particular individuals standing in ongoing and transformative relationships with each other.

One of the consequences of such a model for enacting ethical dialogue is that it is only in the authentic demand to love that one encounters the ' $\mathrm{I}$ ' of one's dialogue-partner. In fact, the other is only able to emerge in their otherness in the mutual interchange of denying oneself in being-open to desiring this particular other, a denial that is made possible by recognizing the tragic isolation that was the case in having rejected, or negated, just this very other. The result of such a voluntary self-denial - a negation of the rejection of that

\footnotetext{
Ibid, 181: "alle Tage hat Liebe das Geliebte ein bißchen lieber."

${ }^{38}$ Rosenzweig refers to the Scandanavian myth of the three "Mothers" in order to introduce a metaphysics of of descending and ascending in 'spiritual' growth. Prior to the experience of a relationship of love, we remain without orientation in the dark of mere monological reason, categorized by Rosenzweig as the metaphysical realm of thinking about thinking, i.e., the realm of dead objectivity.

39 This process is similar to the phenomenology of authenticity to inauthenticity, of Dasein to das Man (or the They) in Heidegger's ontological categorizations. This can also be compared to Husserl's epoché, that is, the movement of intentionality that brackets out or parenthesizes the particular object of regard.

40 Bestand: existence, duration; stability; certitude; strength of a unit Beständigkeit: continuance; permanence; stability; faithfulness die Treue: fidelity, faithfulness; constancy, sincerity, honesty bestehen: how one withstands a test or a fight; how one "stands" through a process, ie., whether one faithfully stays on and "sticks with it" or whether one runs away. It has to do with constancy/duration/certainty and the strength and certainty of one's values.
} 
other - is an increased level of mutual trust between the two who stand in dialogue, a mutual trust which should then lead to the process of Steigerung, or of affirmatively sustaining the growth of one another as a qualified means for helping each other achieve more complete and fulfilling lives. The mediation is qualified for the sake of resisting an ethics of crassly exploiting the other as merely the means of self-serving or self-aggrandizing ends. The process of voluntary self-denial and Steigerung is finalized in the narrative by categorizing the enunciation as a "saying of the Eternal" (Spruch des Ewigen), which crystallizes Rosenzweig's speech-thinking/speech-act treatment of revelation into a receptive focus. The verbal enunciation by the prophet of the "saying of the Eternal," which Rosenzweig also translates as the "saying of God," prepares the listener by leading her to the reception of a speech-claim - a speech-judgment - by an other whose applied validity is unlimited because this judgment is a judgment of the Eternal. The reason why such speech-claims should be applicable to 'all' based on their origin from the 'eternal' is because the concept of the eternal, for Rosenzweig, stands for that which is infinite and open-ended. By contrast, if the origin were the "universal" (Allgemein), it would encompass every one in its universality that represents a return to Hegelian ontology of ethics on the one hand or a Spinozist rational ethics on the other. The easiness of succumbing to such temptations to return is precisely why I would counsel that we follow Rosenzweig's guidance about the sensual/trans-sensual ethical imperative of crossing borders, that is, we need to learn to more attentively listen for the sayings of the other to sense the trace of the eternal - the trans-sensual - in order to be better engage in more responsible speech-acts.

41 A common phrase in German, "Spruch," means a "saying." For example, when strolling through a flea market in Tübingen, Germany one sunny morning, I happened upon a piece of cloth with the phrase "Fleiß bringt Segen" (diligence brings blessing) embroidered on it. Interestingly, Rosenzweig betrays his German "folk" roots by placing importance on the traditionally German virtue of "Fleiß." Such attention to detail is significantly incorporated into Rosenzweig's logic of aesthetics. The obvious significance of his usage is that the prophets begin many of their prophecies with "Thus says the Lord..." or, as Rosenzweig interprets it, "Spruch des Ewigen...." 